${ }^{1}$ University of Colorado, Denver, Anschutz Medical Campus, USA

2 Brigham and Women's Hospital, Harvard Medical School, USA

*Email:

kurt.stenmark@cuanschutz.edu https://doi.org/

10.21542/gcsp.2020.1

Received: 1 March 2020

Accepted: 28 March 2020 (C) 2020 The Author(s), licensee Magdi Yacoub Institute. This is an open access article distributed under the terms of the Creative Commons Attribution license CC BY-4.0, which permits unrestricted use, distribution and reproduction in any medium, provided the original work is properly cited.
Review article

\section{Inflammation, immunity, and vascular remodeling in pulmonary hypertension; Evidence for complement involvement?}

Maria G. Frid ${ }^{1}$, Joshua M. Thurman ${ }^{1}$, Kirk C. Hansen ${ }^{1}$, Bradley A. Maron², Kurt R. Stenmark ${ }^{1 \star}$

\section{ABSTRACT}

Pulmonary (arterial) hypertension ( $\mathrm{PH} / \mathrm{PAH})$ is a life-threatening cardiopulmonary disorder. Experimental evidence suggests involvement of inflammatory and autoimmune processes in pathogenesis of $\mathrm{PH} / \mathrm{PAH}$, however the triggering and disease-promoting mechanisms remain unknown. The complement system is a key arm of innate immunity implicated in various proinflammatory and autoimmune diseases, yet, surprisingly little is known about the role of complement in $\mathrm{PH} / \mathrm{PAH}$ pathogenesis. The preponderance of the existing data associates complement with $\mathrm{PH} / \mathrm{PAH}$ via analysis of plasma and does not study the lung directly. Therefore, we aimed to resolve this by analyzing both the mechanisms of local lung-specific complement activation and the correlation of dysregulated plasma complement to clinical outcome in PAH patients. In our recent studies, reviewed herein, we show, for the first time, that immunoglobulindriven activation of the complement cascade, specifically its alternative pathway, in the pulmonary perivascular areas, is a key mechanism initiating pro-inflammatory processes in the early stage of experimental hypoxic PH (a form of "sterile inflammation"). In human patients with end-stage $\mathrm{PAH}$, we have demonstrated that perivascular deposition of immunoglobulin $\mathrm{G}$ (IgG) and activation of the complement cascade are "longitudinally" persistent in the disease. We also showed, using unbiased network analysis, that plasma complement signaling, including again the Alternative pathway, is a prognostic factor of survival in patients with idiopathic PAH (IPAH). Based on these initial findings, we suggest that vascular-specific, immunoglobulin-driven dysregulated complement signaling triggers and maintains pulmonary vascular remodeling and $\mathrm{PH}$. Future experiments in this area would facilitate discoveries on whether complement signaling can serve both as a biomarker and therapeutic target in $\mathrm{PH} / \mathrm{PAH}$.
Cite this article as: Frid MG, Thurman JM, Hansen KC, Maron BA, Stenmark KR. Inflammation, immunity, and vascular remodeling in pulmonary hypertension; Evidence for complement involvement?, Global Cardiology Science and Practice 2020:1

https://doi.org/10.21542/gcsp.2020.1 


\section{INFLAMMATION IN PULMONARY VASCULAR INFLAMMATION AND REMODELING}

Pulmonary hypertension (PH) encompasses a group of severe clinical entities, including pulmonary arterial hypertension (PAH) where loss and obstructive remodeling of the pulmonary vascular bed is responsible for the rise in pulmonary artery pressure and pulmonary vascular resistance, resulting in progressive right heart functional decline and ultimately failure ${ }^{1,2}$. Patients typically present clinically when disease has become frankly symptomatic, and current treatments can ameliorate but not reverse disease progression. Therefore, a pressing need exists to understand the predisposing risk factors, initiating events, and the mechanisms of disease progression in order to improve early detection and therapy of this devastating syndrome.

At a National Institutes of Health Workshop in 2010, inflammation was acknowledged as an area of emerging interest, and the immune system was proposed as an essential contributor to the pathobiology of $\mathrm{PH}^{3}$. Since then, scientific focus on inflammation in $\mathrm{PH}$ has been increasing. In 2012 the Tuder group, in what is one of the few semi-quantitative studies in the modern era performed to assess pulmonary vascular remodeling, reported a significant correlation between perivascular inflammation and intimal and medial fractional thickness and a strong correlation with pulmonary artery pressure, the only two statistically significant correlations found in the study ${ }^{4}$. Further studies continued to link inflammation to the pathobiology of $\mathrm{PAH}^{5,6}$. Vascular inflammation can be associated with numerous pulmonary insults, including so-called "sterile inflammation", which may arise in the context of environmental stresses, including hypoxia and sheer stress, in response to damage associated molecular patterns (DAMPs) released into the extracellular environment ${ }^{7}$. Moreover, chronic inflammation in PAH is associated with auto-immune forms of the disease ${ }^{8}$. However, the mechanisms triggering activation of the immune system and development of auto-immunity in PAH remain unknown.

There is strong evidence to suggest that inflammatory diseases of the vessel wall are largely orchestrated from the outside in ${ }^{9-11}$. Several groups, including ours, demonstrated that the vascular adventitia is a key site of immune activation ${ }^{12-14}$. It is increasingly appreciated that inflammatory responses are unique to the tissue where the inflammation occurs ${ }^{9,15}$. The idea has emerged that there is significant diversity in stromal cells, particularly in fibroblasts, and that function varies considerably among these subsets of cells, which have previously been lumped simply as "fibroblasts." Our recent data suggest that one of the subsets of fibroblast-like cells that exists in the pulmonary hypertensive vascular wall is characterized by inflammatory cytokine production that exceeds that of other fibroblasts, SMCs, and ECs ${ }^{14,16-18}$.

Other fibroblast subsets exist that are functionally more similar to traditional myofibroblasts, while there are others that have anti-inflammatory properties. There is strong evidence that in the initial phases of $\mathrm{PH}$ in the animal models currently available, the earliest inflammatory responses occur in the adventitia ${ }^{14}$. In chronic persistent disease, this inflammation persists but then often involves both the medial and the intimal layers. This is consistent with the idea that in most normal arteries, the media is an immune-privileged site ${ }^{19}$.

Human studies clearly demonstrate that the most intense inflammatory responses in late-stage human PH are observed in the adventitia ${ }^{12}$. Thus, we posit that, although the nature of initial damage to the vascular wall can vary with different types of injuries in both the systemic and the pulmonary circulation, mounting evidence strongly supports the idea that peri-vascular inflammation may act as a driving force in the development of subsequent medial and intimal remodeling. Thus, it seems possible that inflammation 


\section{Complement Cascade}

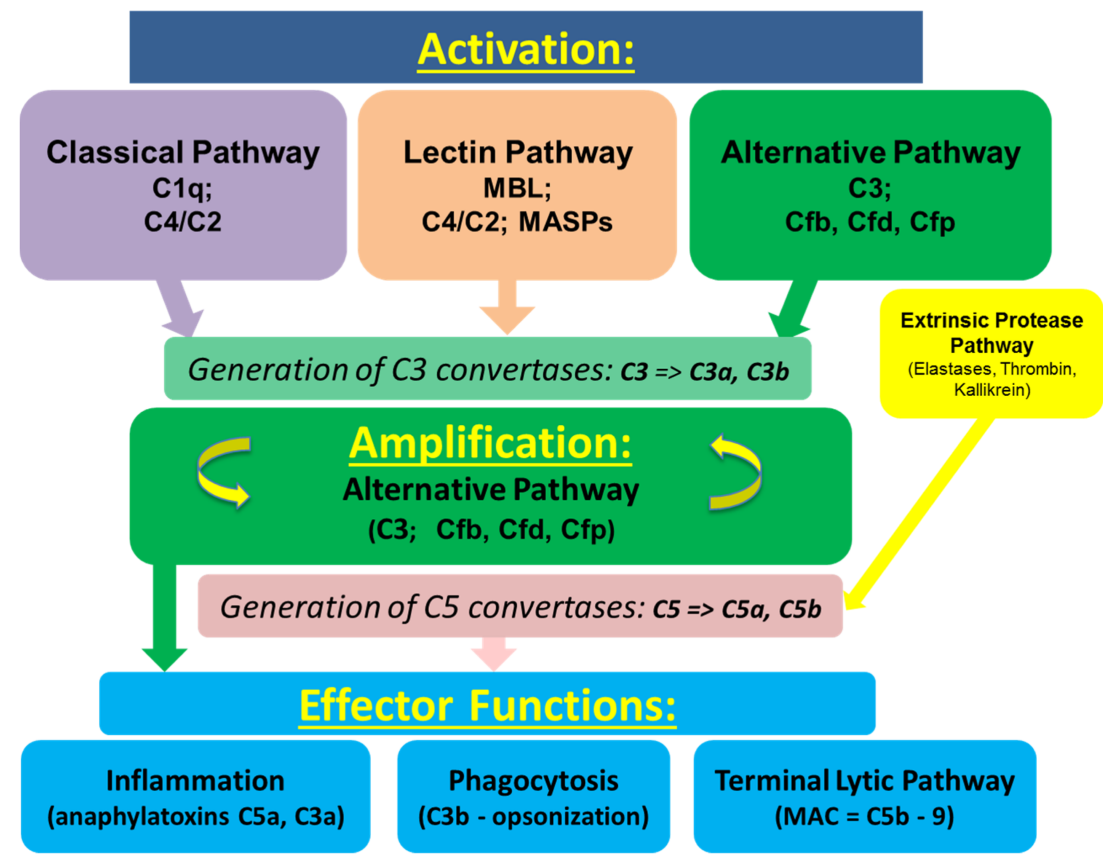

Figure 1. Schematic representation of complement cascade. Note that only a limited number of the components of each activation pathway is presented, and complement inhibiotors/regulators are not shown.

represents a central mechanistic link between adventitial activation and vascular changes in response to a variety of stimuli. Elucidating the mechanisms contributing to this apparently microenvironmentally specific inflammation will be critical to understand inflammation and remodeling in $\mathrm{PH}$.

\section{COMPLEMENT: OVERVIEW}

Complement is a cornerstone of innate immunity, playing a key role in host homeostasis, inflammation, and defense against pathogens and unwanted host elements. This system consists of a network of nearly 50 circulating, membrane-bound, and intracellular proteins and protein fragments activated by limited proteolysis in a cascade-like fashion (much like the coagulation cascade). Complement activation occurs via 3 major interconnected pathways (Figure 1):

(1) the classical, involving antibody-mediated activation via the $\mathrm{C}_{1}$ complex (comprising $\mathrm{C}_{1 \mathrm{q}}$ as the main component), resulting in cleavage of $\mathrm{C}_{2}$ and $\mathrm{C}_{4}$ components;

(2) the lectin, triggered by carbohydrates (such as, for example, mannose-binding lectin) on cell surfaces, and resulting in cleavage of $\mathrm{C}_{2}$ and $\mathrm{C}_{4}$ components; and

(3) the alternative, which involves cleavage of $C_{3}$ facilitated by complement factors $B, D$, and and stabilized by properdin $20-23$.

These pathways all converge onto formation of $\mathrm{C}_{3}$ convertases, which catalyze proteolysis of complement component $\mathrm{C}_{3}$ into the smaller $\mathrm{C}_{3}$ a (anaphylatoxin) and the larger $\mathrm{C}_{3} \mathrm{~b}$ fragment. $\mathrm{C}_{3} \mathrm{~b}$ fragment associates with the $\mathrm{C}_{3}$ convertases to further form the $C_{5}$ convertase that catalyzes the cleavage of complement component $C_{5}$ into the smaller C5a (anaphylatoxin) and the larger $C_{5} b$, which initiates the subsequent assembly of the membrane attack complex (C5b-9, MAC). 
The numerous proteolytic complement fragments generated from the activation cascade provide crosstalk with other effector and regulatory systems, and functions as a bridge between innate and adaptive immune responses, interacting with several cell types, including macrophages, T- and B-cells, and platelets ${ }^{20,21}$.

Uncontrolled activation of the complement system can be very damaging to host tissues, and thus the complement cascade is very tightly controlled by soluble and cell membrane-bound regulators/inhibitors from the "regulators of complement activation" (RCA) family. These proteins act to avert the formation of convertase complexes on host cells and/or destabilize the preformed ones. Complement exerts functions well beyond those of detecting, killing, and removing invading microorganisms. For example, complement assists in the clearance of immune complexes, cellular debris, self-altered and apoptotic cells, and plays an essential role in pregnancy, CNS and other organ early development and in aging $^{24}$.

This system is also involved in several non-immunologic processes, such as coagulation, angiogenesis, tissue repair, and generating a resistance to cell death, all of which have been linked to the pathogenesis of $\mathrm{PAH}^{22,25}$.

Collectively, these studies have demonstrated that complement is not a strictly intravascular system, but also one in which local secretion of complement components by tissue and infiltrating cells, and potentially even intracellular complement turnover contribute to complement-driven responses ${ }^{25,26}$. Recent work also supports the idea that locally or intracellularly generated complement fragments (anaphylatoxins, in particular) may have properties/functions that are different from their plasma counterparts. It is also important to note that cleavage of $C_{5}$ complement can be achieved by an unconventional convertase-independent pathway (so-called "extrinsic protease pathway") through other enzymes such as cathepsins, elastases, thrombin, and kallikrein ${ }^{27,28}$.

The diverse roles of complement have provided support for the concept that complement $\mathrm{C}_{3}$ a and $\mathrm{C}_{5}$ a anaphylatoxins participate in many of the classic processes that are hallmarks of cancer, as proposed by Hanahan and Weinberg ${ }^{29}$. This prompted several groups to examine the hypothesis that complement is activated in established tumors and pre-neoplastic lesions ${ }^{30-32}$.

Recent studies have revealed that complement activation can in fact promote the spread of tumors ${ }^{33}$. These effects are likely mediated through the anaphylatoxins $\mathrm{C}_{3} \mathrm{a}$ and $\mathrm{C}_{5}$ a, produced during complement activation, acting on immune and inflammatory cells through specific cell surface receptors ( $C_{3} a R$ and $\left.C_{5} a R_{1} / 2\right)$. Further, it was found that $\mathrm{C}_{3} \mathrm{a}$ and/or $\mathrm{C}_{5}$ a anaphylatoxins can exert profound influence on the tumor microenvironment by inducing a series of context-dependent changes, including: recruitment of tumor-promoting macrophages and CC-chemokine ligand 2 (CCL2) production34; a decrease in recruitment of $\mathrm{CD}_{4}+\mathrm{T}$-cells, neutrophils, and natural killer (NK) cells ${ }^{35,36}$; stimulation of a pro-tumoral phenotype for $\mathrm{CD}_{4}+\mathrm{T}$-cells and inhibition of IL10 expression by intramural CD8+ T-cells ${ }^{37}$; stimulation of pro-tumorigenic properties of mast cells and macrophages, including suppression of CD8+ T-cells cytotoxicity ${ }^{28}$; and promotion of pro-tumoral neutrophil extracellular trap (NET) formation ${ }^{38}$. However, work regarding the role of complement in tumor initiation and progression is far from over. Design of efficient complement-targeted therapeutics for cancer would require a better understanding of the mechanisms by which complement components contribute to tumor progression. 


\section{ROLE OF COMPLEMENT IN PULMONARY VASCULAR INFLAMMATION AND REMODELING}

Our and others' work in humans with PAH and animal PH models recorded observations of cancer-like properties of cells from the hypertensive vessel wall, including excessive proliferation and apoptosis resistance, as well as early and persistent perivascular accumulation of monocytes/macrophages, augmented expression of proinflammatory cytokines/chemokines (GM-CSF, CCL2, CX3CL1, CXCL12, IL6), and immune dysregulation ${ }^{11,12,39-44}$.

However, until recently, little work has been performed to investigate the role of complement in the pathogenesis of $\mathrm{PH} / \mathrm{PAH}$. The preponderance of data, with the exception of a sole report 45 , associate complement with $\mathrm{PAH}$ via analysis of circulation 46-48.

Until recently, this knowledge gap has cast uncertainty on the translational importance of complement to the pathogenesis of PAH. To begin to address this important issue, our group has recently worked to evaluate both the local lung-specific complement-driven processes and the correlation of dysregulated complement to clinical outcome in PAH patients.

\section{Proteomic analysis of the complete matrisome in pulmonary arteries identifies complement and coagulation cascades as top upregulated pathways}

There is intense interest in identifying key proteins involved in the PH disease process as they may provide potential targets of new therapies. The vast majority of work in this area has focused on changes in mRNA occurring during disease development using mRNA analysis of whole lung tissue. To our knowledge, there has not been a comprehensive study of the changes in the protein composition specifically of large or small pulmonary arteries in $\mathrm{PH}$. We thus set out to perform a detailed analysis of the pulmonary vascular proteome in pulmonary hypertension.

Dr. Kirk Hansen has developed and optimized protocols for extraction of extracellular matrix (ECM) and matricellular proteins that have been refined using samples from a variety of sources, including tissue engineering studies ${ }^{49-52}$. He and colleagues have applied the protocols to samples based on cell culture, mouse tumors $53^{-56}$ and patient tumors 55,57 and over a dozen mouse organs ${ }^{58-61}$. Using these methods, Dr. Hasen's laboratory has consistently identified the majority of ECM proteins (>99\%) in both the soluble and, more importantly, insoluble fractions of the whole tissue extract.

Quantification of the proteins, which has not previously been accomplished, was performed using a version of the quantitative concatamer (QconCAT) approach via a library of stable isotope-labeled (SIL, usually ${ }^{13} \mathrm{C}_{6}$ - Lys or Arg) reporter peptides mixed with the samples before digestion ${ }^{62,63}$. Numerous ECM datasets collected in Dr. Hansen's lab, as well as public data repositories have been utilized to select reporter "proteotypic" peptides for all observed ECM proteins, common cellular contaminants, proteins involved in ECM processing and internal standard proteins (850 total). Using these approaches, over 1300 proteins were examined in decellularized proximal and distal pulmonary arteries from control and hypoxic-hypertensive calves (an animal model of severe hypoxic $\mathrm{PH})^{64}$ at 2 distinct time points in the $\mathrm{PH}$ disease process (early/14-days and late/16months). Principal component analysis of the data demonstrated distinct differences between the control and $\mathrm{PH}$ proteasomes (Figure 2).

Interestingly, pathway analysis revealed that the most upregulated signaling pathway in the early stages of the disease process in both proximal and distal pulmonary arteries was related to activation of the complement and coagulation cascades (not shown). The 


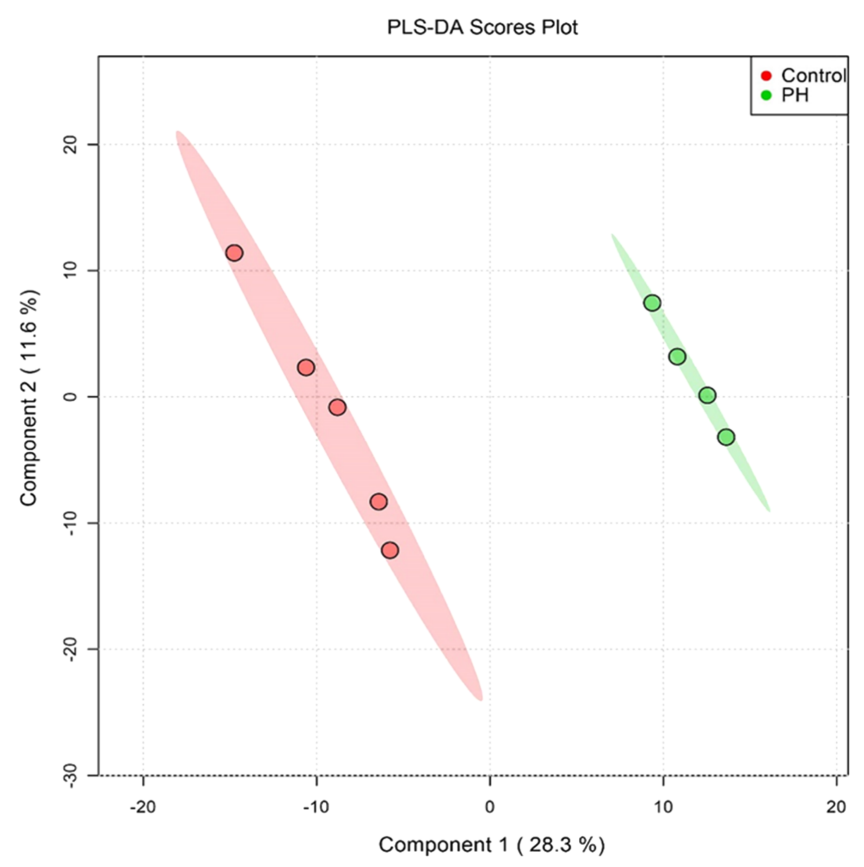

Figure 2. Proteomic analysis of whole distal pulmonary arteries from neonatal (15-day old) calves (control and chronically hypoxic) demonstrates profound differences in the proteome (PC analyses).

data also demonstrate marked differences in the matrisome composition of different size vessels and at different times in the disease process. Whether these data are reflective of homogeneous change in the lung vessels or whether indeed there is heterogeneity within the proteasome related to specific type or degree of vascular remodeling remains to be investigated.

However, these observations stimulated us to pursue the role of complement in $\mathrm{PH}$, specifically, when in the disease process and by what means complement was activated in the lung vasculature.

\section{Vascular-specific complement activation in chronic experimental PH models and} human PAH

First, we searched to determine the evidence for local complement production and activation in experimental PH models and in human PAH. We evaluated localization of complement cascade activation via immunostaining for deposited C3d (the final activation/degradation fragment of complement $C_{3}$, commonly accepted as a marker of activated complement cascade ${ }^{65}$ ), using a monoclonal antibody (mAb-C3d29) developed by Dr. Thurman and colleagues. This mAb specifically detects a covalently attached C3d fragment and not simply the presence of plasma-derived ("leaked") C 3 in the vessel wall ${ }^{65}$. C3d deposition was consistently observed in a perivascular-specific pattern in the lungs of mice, rats and calves with experimental chronic (2-3 week) hypoxic $\mathrm{PH}$, and in rats with monocrotaline (MCT) PH and/or Sugen+hypoxia PH (Figure 3).

C3d deposition was also detected in pulmonary perivascular areas of IPAH patients, with evidence of occasional presence within the neointima of arteries with intimal thickening. C3d deposition in normal lung (rejected donors) was minimal to absent. Collectively, these data generated in different experimental PH models, at different stages of the disease process, and across species decisively demonstrated that complement 


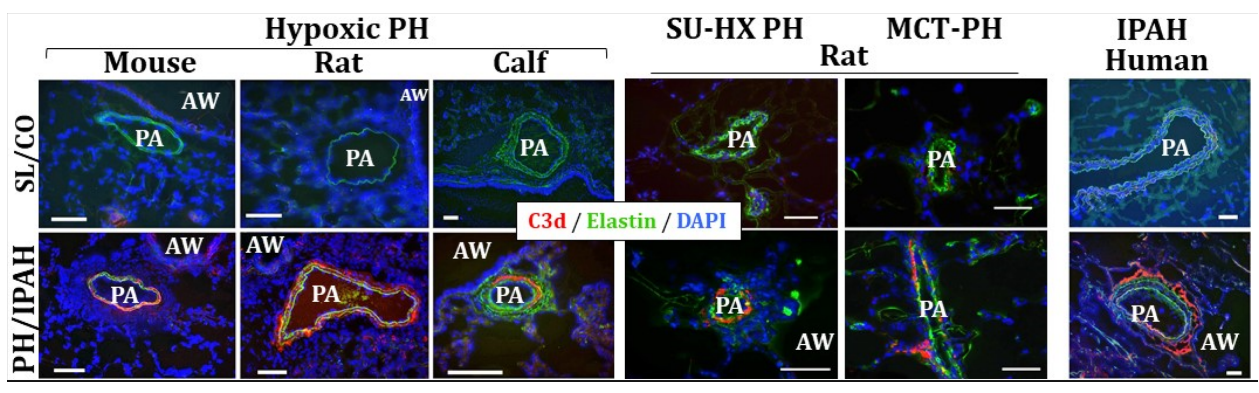

Figure 3. Activation of the complement cascade, as defined by deposition of $C_{3} d$ (terminal degradation fragment of $\mathrm{C}_{3}$ activation) is observed in a perivascular-specific pattern in the lungs of experimental animal models of $\mathrm{PH}$ (3-week hypoxic mice and rats; 2-week hypoxic calves; and rats with sugen-hypoxia (SU-HX)- or monocrotaline (MCT)-induced PH) and in humans with idiopathic PAH (IPAH). No deposition of $\mathrm{C}_{3} \mathrm{~d}$ is observed in normal control lungs. Cryosectiones were immunolabeled with C3d-specific monoclonal antibody mAbs-C3d29 (red fluorescence), which distinguishes tissue-bound $C_{3}$ d from $C_{3}$ or C3b. Pulmonary arteries (PAs) are visualized by autofluorescence of elastic lamellae (green). AW, airways. Cell nuclei are labeled with DAPI (blue fluorescence). Scale: $100 \mu \mathrm{m}$.

activation is a longitudinal marker of PH/PAH. An important observation was of pulmonary perivascular-specific activation of the complement cascade.

Very little is known of the initiating mechanisms involved in the PH disease process due to lack of tissues at the very early stages of human disease. Therefore, we began a series of studies using experimental animal models, and specifically hypoxic rodents (mice and rats).

\section{Hypoxia causes activation of the complement cascade in a pulmonary vascular- specific manner}

Short exposure of mice and rats to hypobaric hypoxia resulted in robust and vascularspecific deposition of complement component $C_{3}$, suggesting initiation of activation of the complement cascade (Figure 4) (as of note, deposition of $C_{3}$ d fragment was not detected at this early time point). Increased numbers of perivascular cells expressing receptors for the anaphylatoxins $C_{5}$ a and $C_{3}$ ( $C_{5} a R_{1}, C_{3} a R_{1}$, respectively) was also observed and quantified.
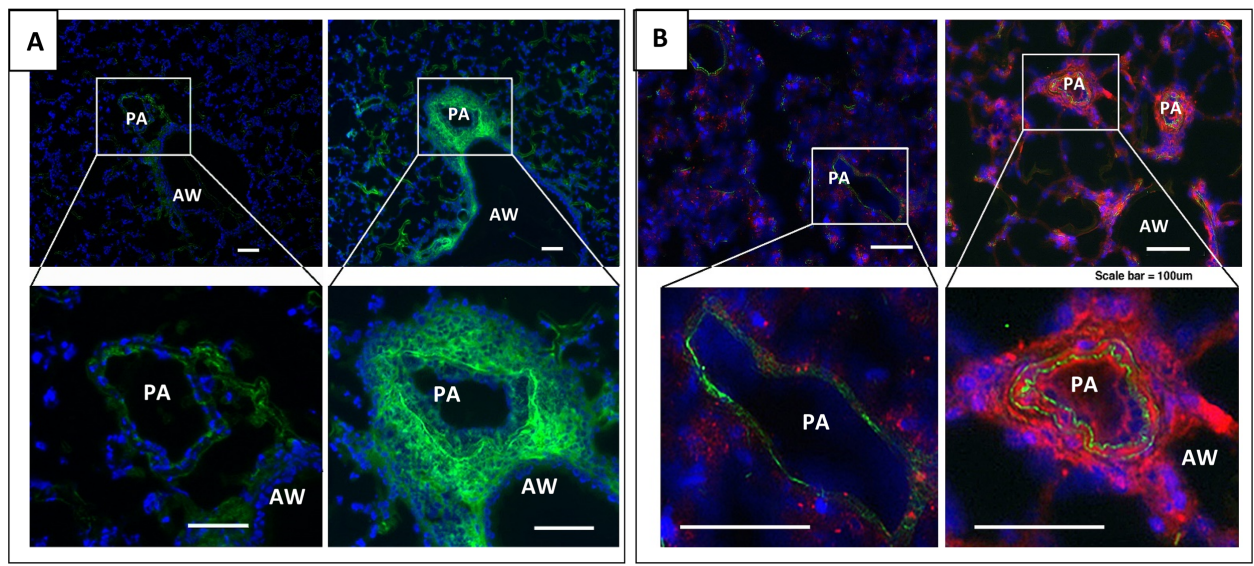

Figure 4. Hypoxia (3 day exposure) induces deposition of complement component $C_{3}$ in pulmonary vascular-specific pattern in mice ( $A$, green fluorochrome) and rats $(B$, red fluorochrome). PA, pulmonary artery; AW, airway. Scale, $100 \mu \mathrm{m}$. 


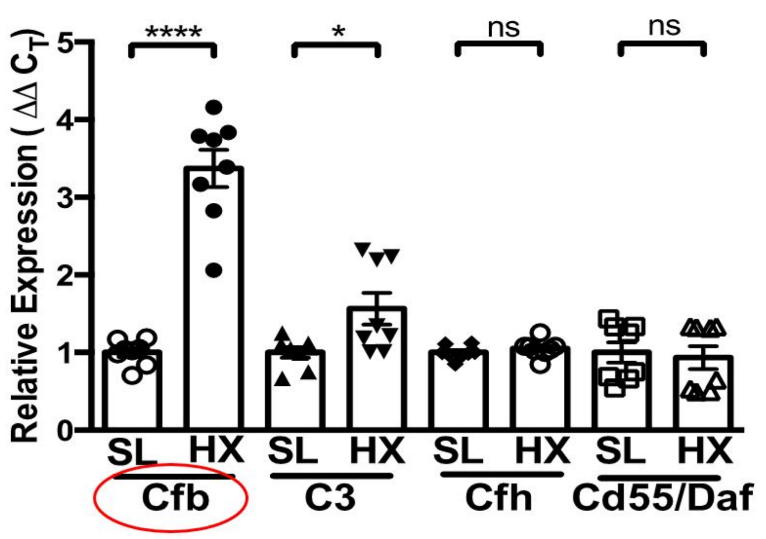

Figure 5. RT-PCR analysis of whole lung extracts from 3-day hypoxic (HX) wild-type ( $\left.C_{57} B L 6\right)$ mice, compared to sea-levloe (SL) controls, demonstrates robust augmentation of complement factor $B(\mathrm{Cfb})$, modest upregulation of complement $\mathrm{C}_{3}$, and no alterations in expression of complement inhibitors/regulators (complement factor $\mathrm{H}$ (Cfh), and Cd55/Daf), thus shifting the balance toward local activation of the alternative complement pathway. ${ }^{\star} P \leq 0.05$; $\star \star \star \star P \leq 0.0001$; ns, not significant.

Furthermore, robust augmentation in the mRNA expression of complement factor B (Cfb, a key activator of the alternative pathway) was detected in whole lung extracts, with no significant changes in expression of complement inhibitors (i.e. complement factor $\mathrm{H}$ (Cfh) of the alternative pathway, and $\mathrm{Cd}_{55} /$ Daf, decay-accelerating factor), thus shifting the balance toward activation of the complement cascade (Figure 5) ${ }^{66}$.

Collectively, these data provided evidence that the alternative complement pathway is a critical hypoxia-induced constituent in the initiation/early stage of hypoxic $\mathrm{PH}$, in line with observations in other sterile inflammatory injuries ${ }^{7,67}$.

\section{Hypoxia-induced pulmonary perivascular inflammation and cell proliferation are complement-dependent}

First, we evaluated whether complement activation was involved in regulation of specific cellular/molecular events characteristic of the early stage of hypoxia-induced $\mathrm{PH}$ (monocyte/macrophage accumulation, cytokine/chemokine production and cell proliferation). To determine that, as well as specific complement components/pathways involved, we used mice genetically deficient in C3 (main component of the alternative pathway), Cfb (essential activator of the alternative pathway), and $C_{5}$ (main component of the terminal/MAC pathway).

Perivascular accumulation of macrophages was assessed by immunostaining of lung sections for macrophage marker CD68 and via RT-PCR analysis of whole lung extracts. Mice deficient in Cfb (alternative pathway) and/or C5 (terminal / MAC pathway) were significantly protected from perivascular recruiment/accumulation of $\mathrm{Cd} 68+$ cells at 3-day hypoxic exposure. Intriquinly, and in contrast to the previously report ${ }^{45}, \mathrm{C}_{3}$ deficient mice exhibited a higly pro-inflammatory phenotype, which could be explained by other work demonstrating high level of anaphylatoxin $\mathrm{C}_{5}$ a generation in $\mathrm{C}_{3}$-deficient mice due to thrombin production and $\mathrm{C}_{3}$-convertase independent cleavage of $\mathrm{C}_{5}$ complement ${ }^{27}$.

Because recruitment and activation of pro-inflammatory monocytes/macrophages in $\mathrm{PH}$ is known to be driven by chemokines/cytokines, such as $\mathrm{Ccl}_{2} / \mathrm{MCP} 1$ and $\mathrm{Csf}_{2} / \mathrm{GM}$ $\mathrm{CSF}^{68}$, we next evaluated expression of these chemokines/cytokines in wild-type and complement-deficient mice. In 3-day hypoxic wild-type mice, expression of both 
$\mathrm{CCl}_{2} / \mathrm{MCP} 1$ and $\mathrm{Csf}_{2} / \mathrm{GM}$-CSF was robustly upregulated in pulmonary arteries and airways, as compared to sea-level wild-type controls.

Lungs of Cfb-and $\mathrm{C}_{5}$-deficient 3-day hypoxic mice demonstrated significant attenuation of $\mathrm{CCl}_{2} / \mathrm{MCP} 1$ expression, and most remarkably, near complete abrogation of pulmonary Csf2/GM-CSF expression, which was confirmed both via RT-PCR analysis of whole lung extracts and RNAscope in situ hybridization in lung sections. The latter observation is of importance, as GM-CSF/CSF2 has emerged as a potent mediator of tissue, and specifically lung inflammation ${ }^{68,69}$. GM-CSF shows minimal levels in normal circulation, but can be locally produced at sites of inflammation, and promotes recruitment, pro-survival re-programming and pro-inflammatory activation of monocytes/macrophages, as well as participates in the induction of the inflammasome ${ }^{70}$.

Interestingly, among various myeloid types, only the inflammatory Ly6Chigh $/ \mathrm{Ccr}_{2}{ }^{+}$ monocytes are vitally dependent on GM-CSF to instigate lung tissue inflammation and damage ${ }^{70}$, and a recent study reported increased numbers of these Ly6Chigh $/ \mathrm{CCR}_{2}{ }^{+}$ monocytes in the blood and lungs of hypoxic mice ${ }^{71}$. Collectively these reports and our study demonstrate that hypoxia-induced pro-inflammatory monocyte expansion is dependent on GM-CSF signaling, which is in turn induced by local complement activation in the pulmonary vascular adventitia. Further support for these data comes from cell culture experiments using human pulmonary adventitial fibroblasts obtained from PAH patients. We evaluated GM-CSF responses to complement activation in these cells and observed that both mRNA and protein CSF2/GM-CSF expression was highly dependent on complement cascade activation via the alternative pathway.

We have additionally demonstrated that hypoxia-induced pulmonary perivascular cell proliferation, which is yet another feature of an early stage of $\mathrm{PH}$ disease process, is also complement (and, specifically, alternative and C5/terminal pathways)-dependent. Increased levels of perivascular cell proliferation, observed in 3-day hypoxic wild-type mice, were significantly attenuated in $\mathrm{Cfb}$ - and $\mathrm{C}_{5}$-dericient hypoxic mice.

Collectively, these observations will stimulate important future work to determine whether specific local tissue targeting of complement activation can interrupt the pro-inflammatory and pro-proliferative responses that are critical in $\mathrm{PH}$ initiation and progression.

\section{Hypoxia-induced immunoglobulin deposition contributes to complement activation and perivascular pro-inflammatory, pro-proliferative processes}

Having established an essential role of complement signaling in hypoxia-induced inflammation and cell proliferation, we set on identifying the upstream triggers of complement activation in this (hypoxic) model of sterile inflammation. As previous studies have suggested an important role of (auto)immune mechanisms in pathophysiology of $\mathrm{PH} / \mathrm{PAH}^{43}$, we evaluated the contribution of immunoglobulins (Igs) to hypoxia-induced complement activation and vascular inflammation and remodeling.

Pulmonary vasculature of 3-day hypoxic rodents (mice and rats) demonstrated profound vascular-specific deposition of both IgM and IgG, yet in very distinct compartmentalized patterns. IgM deposition was restricted to luminal/medial vascular layers and correlated with deposition of complement $\mathrm{C}_{4}$ (the main component of the classical and lectin pathways), whereas deposition of IgG was detected in all vascular layers, with most prominent deposition in the perivascular adventitia, and correlated with deposition of complement $\mathrm{C}_{3}$ (the main component of the alternative pathway) (Figure 6).

Normal control lungs were completely devoid of IgM, IgG, C4, or C3. These observations led us to evaluate hypoxia-induced responses (complement activation 


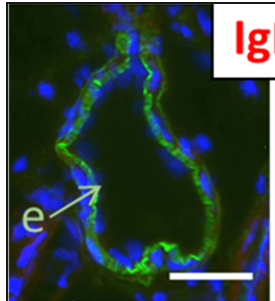

SL

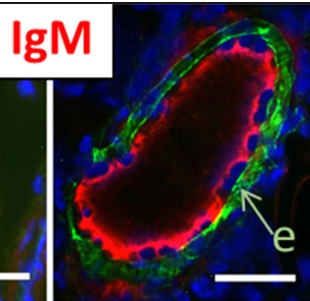

$\mathrm{HX}$

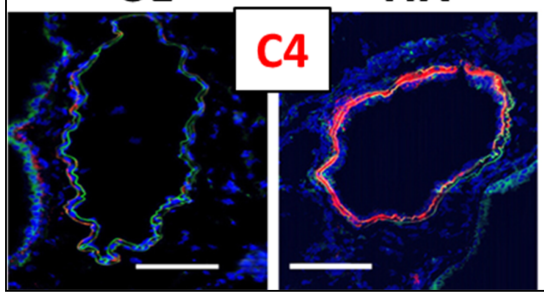

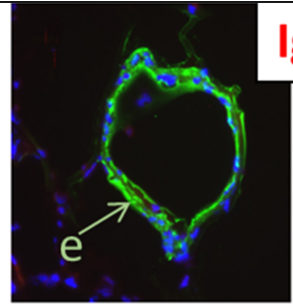

SL

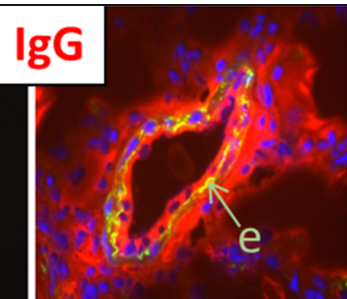

HX

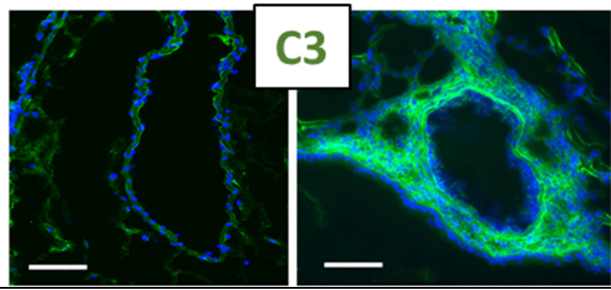

Figure 6. Early (3-day) hypoxia-induced deposition patterns of IgM and IgG are highly compartmentalized (luminal for IgM, and all vascular layers, with most prominent adventitial deposition, for IgG), and correlate with localization/deposition patterns of complement components $\mathrm{C}_{4}$ (classical activation pathway) and $\mathrm{C}_{3}$ (alternative pathway), respectively. SL, sea-level; HX, hypoxia.

and pro-inflammatory/pro-proliferative processes) in immunoglobulin-deficient $\mu$ MTmouse strain (deficient in all circulating lgs) ${ }^{72}$. Remarkably, $\mu$ MT- mice demonstrated marked protection from hypoxia-induced vascular changes (no detectable complement activation; reduced accumulation of CD68+ macrophages and Ccl2/MCP1 expression; near complete abrogation of Csf2/GM-CSF expression; and significant decreases in cell proliferation) (Figure 7 A).
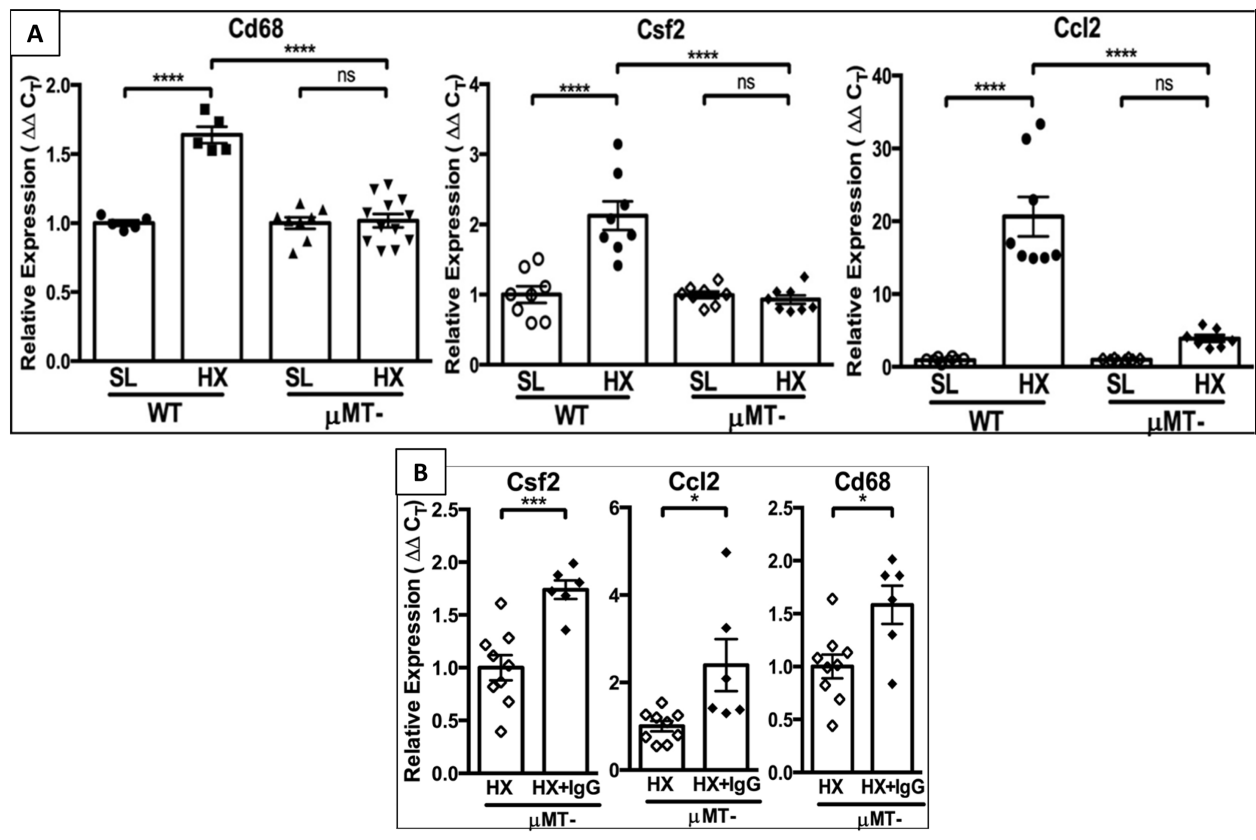

Figure 7. (A): RT-PCR analysis of whole lung lysates shows that immunoglobulin-deficient $\mu M T-$ mice exhibit a "hypoxia-protected" phenotype (abrogated expression of macrophage marker CD68, pro-inflammatory cytokine $\mathrm{Csf}_{2} / \mathrm{GM}$-CSF and chemokine $\mathrm{Ccl}_{2} / \mathrm{MCP}_{1}$ ) as compared to hypoxic wild-type (WT) mice. (B): Reconstitution of hypoxic $\mu M T$ - mice with $\lg G(H X+\mid g G)$ restores a "hypoxic" pro-inflammatory phenotype as demonstrated via RT-PCR analysis of whole lung lysates. 
Since all the examined hypoxia-induced processes (such as recruitment/accumulation of macrophages, $C_{3} \mathrm{aR} / \mathrm{C}_{5} \mathrm{aR}$ and cytokine/chemokine expression, and cell proliferation) occurred in perivascular adventitia of hypoxic mice and strongly correlated with deposition of IgG (but not IgM), we next performed experiments to determine whether reconstitution of hypoxic $\triangle M T$ - mice with IgG to its normal circulating levels would reverse the observed protection. Using an IgG injection protocol, similar to that in human immunodeficient patients ${ }^{73,74}$, we observed restoration of the features of pathological hypoxia-induced "wild type-like" phenotype in $\triangle M T$ - mice, including perivascular activation of complement (deposition of $\mathrm{C}_{3}$ ), increased accumulation of $\mathrm{CD}_{6}{ }^{+}, \mathrm{C}_{5} \mathrm{aR}_{1}{ }^{+}$macrophages, upregulated expression of $\mathrm{CCl}_{2} / \mathrm{MCP}_{1}$ and $\mathrm{Csf} / \mathrm{GM}-\mathrm{CSF}$, and increased cell proliferation (Figure $7 \mathrm{~B}$ ).

Collectively, these data indicate a central contribution of IgG to hypoxia-induced pro-inflammatory and pro-proliferative changes in the lung vasculature, and support the notion that, at least certain forms of $\mathrm{PH}$, may be characterized by an immunemediated component. Indeed, previous studies have reported detection of circulating autoantibodies in $\mathrm{PH} / \mathrm{PAH}$ patients, as well as the presence of activated bronchusassociated lymphoid tissues in the lungs of patients with $\mathrm{PAH}^{41,75}$. However, specific mechanisms involved in this autoimmune dysregulation have not been explained and, specifically in hypoxic forms of sterile inflammation, remain unclear. Conventionally, the classical pathway of complement activation has been held responsible for inducing antibody-mediated complement activation, wherein pentameric IgM is more effective in activating complement than monomeric lgG.

However, it has been reported that certain IgG-immune complexes can activate the lectin pathway and have also been suggested to drive the alternative pathway ${ }^{76,77}$. It is important to note that the free $C_{3} b$ cleavage fragment (the main component of the C3 convertase) is short lived but becomes stable when covalently bound to certain IgG molecules or to cell surfaces, thus forming complexes that are more stable than C3b itself. In addition, tissue deposition of IgG may render the cell surface advantageous for alternative pathway propagation by diminishing the binding of the alternative pathway inhibitor, complement factor $\mathrm{H}(\mathrm{Cfh})^{76}$. Our data thus, when taken in context of other reports, support the idea that, at least in some immune complex-mediated $\mathrm{PH} / \mathrm{PAH}$ cases, the alternative pathway can serve as a critical facilitator of inflammatory dysregulation -most likely in its role as a potent amplification loop, following initiation by the classical and/or lectin pathways.

Furthermore, the IgG/ $\mu$ MT- mouse reconstitution experiments led us to propose that, early in exposure to hypoxia, naturally occurring, so called "natural antibodies" (N-Abs), recognize and bind to neo-epitopes generated via hypoxic injury on resident pulmonary vascular wall cells. Natural antibodies are normally present in the circulation of healthy subjects in the absence of exogenous antigen stimulation (i.e. they are preexisting antibodies and can exert first response regulatory functions $)^{78}$. At present, the identity of hypoxia-generated neo-epitopes recognized by circulating N-Abs is not known and is of interest.

\section{Plasma complement is a critical determinant of clinical outcomes in patients with PAH}

It has become increasingly clear that the $\mathrm{PH}$ pathobiology and even the contribution of inflammation to the PAH process is highly heterogeneous. Technologies are now available and allow advancement of studies focused on deep PAH phenotyping ${ }^{79,80}$. A recent study by Sweatt et al. ${ }^{80}$ demonstrated that blood cytokine profiles can distinguish 

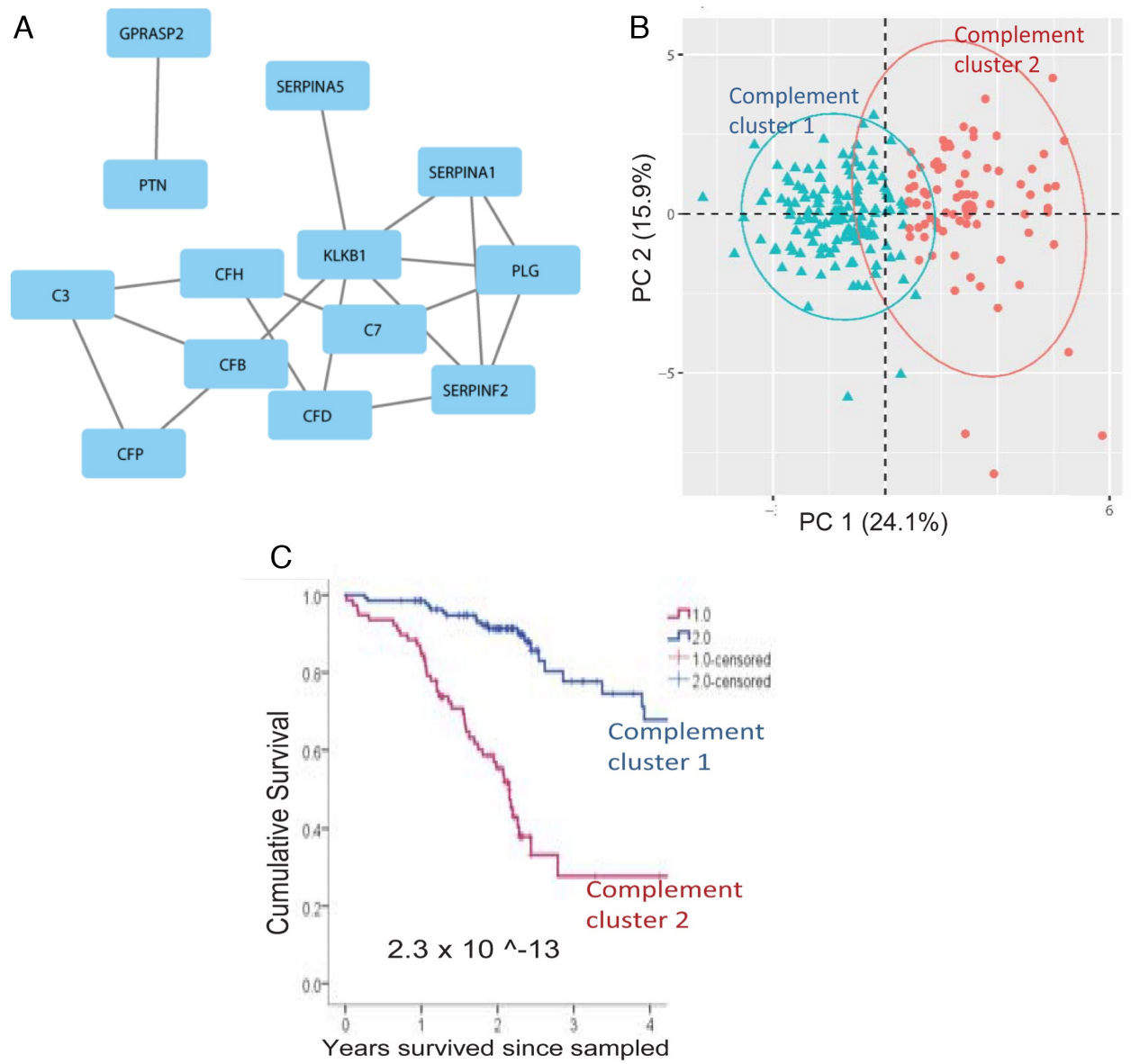

Figure 8. Plasma complement is a critical determinant of clinical outcomnes in patients with PAH. (A): Previously published data ${ }^{46}$, identifying circulating proteins with prognostic importance to PAH patients, were analyzed using a network medicine approach. Differentially expressed proteins were mapped to the consolidated human interactome resulting in a network that was enriched with complement pathway intermediaries, the "complement-PAH network" (13 proteins (blue boxes) and 18 protein-protein interactions (grey lines)). (B): Two distinct patient clusters were identified based on biological information derived solely from the "complement-PAH network". Oval represents the estimated cluster boundaries determined by the patient data in each cluster. (C): Kaplan-Meier survival estimates in patients divided into two clusters (as shown in B) based on the plasma levels of proteins in the "complement-PAH network" are presented; thin vertical marks indicate where patients were censored during the time course.

PAH immune phenotypes with differing clinical risk that are independent of traditional WHO Group 1 subtypes. This study showed that these phenotypes could inform mechanistic studies of disease pathobiology and provide a framework to examine patient responses to emerging therapies.

Another study by Rhodes et al. demonstrate that a panel of nine circulating biomarkers could predict, with some certainty, PAH disease progression ${ }^{46}$. Our observations, in collaboration with Drs. Brad Maron (Harvard University), Martin Wilkins (Imperial College of London) and colleages, support and expand these findings. Using network medicine to explore the integrated biological pathways that are important in PAH clinically, our findings demonstrate that clinical outcomes in PAH patients can be determined by a "complement-PAH network". This name was assigned to the protein network network since it was heavily populated by complement intermediaries, particularly those of the alternative pathways ( $\mathrm{C}_{3}, \mathrm{Cfd}, \mathrm{CfH}, \mathrm{CfP}$, and $\mathrm{C}_{7}$ of the terminal (MAC) pathway)

(Figure 8A). 
The expression profile of proteins in the complement-PAH network alone was sufficient to identify two distinct patient subgroups (Figure 8B), which corresponded to significant and meaningful differences in the rate of all-cause mortality (Figure 8C).

These observations provide further data, which can be useful toward clarifying molecular mechanisms underpinning the role of complement in $\mathrm{PH} / \mathrm{PAH}$. The data in the human condition and its relevance to animal data were also validated by findings of almost identical perivascular-specific patterns of complement activation in the lungs of experimental PH animals and IPAH patients. Future studies will be needed to evaluate the influence of various types of complement activation on specific immune phenotypes in $\mathrm{PH} / \mathrm{PAH}$ and, more importantly, to correlate blood and complement/immune phenotypes to the diversity of vascular lesions observed in $\mathrm{PH} / \mathrm{PAH}$, using the transcriptomic and proteomic approaches that are currently available.

\section{CONCLUSIONS AND SPECULATIONS}

The presented and reviewed data establish, we believe for the first time, an essential causal role of immunoglobulin-driven complement activation in the early proinflammatory, pro-proliferative stage of hypoxic PH (form of sterile inflammation) (Figure 9). Dysregulated complement activation is also consistently observed in later stages of $\mathrm{PH}$ pathobiology in various experimental animal $\mathrm{PH}$ models, and appears as an important correlative determinant of clinical outcomes in PAH patients, thus

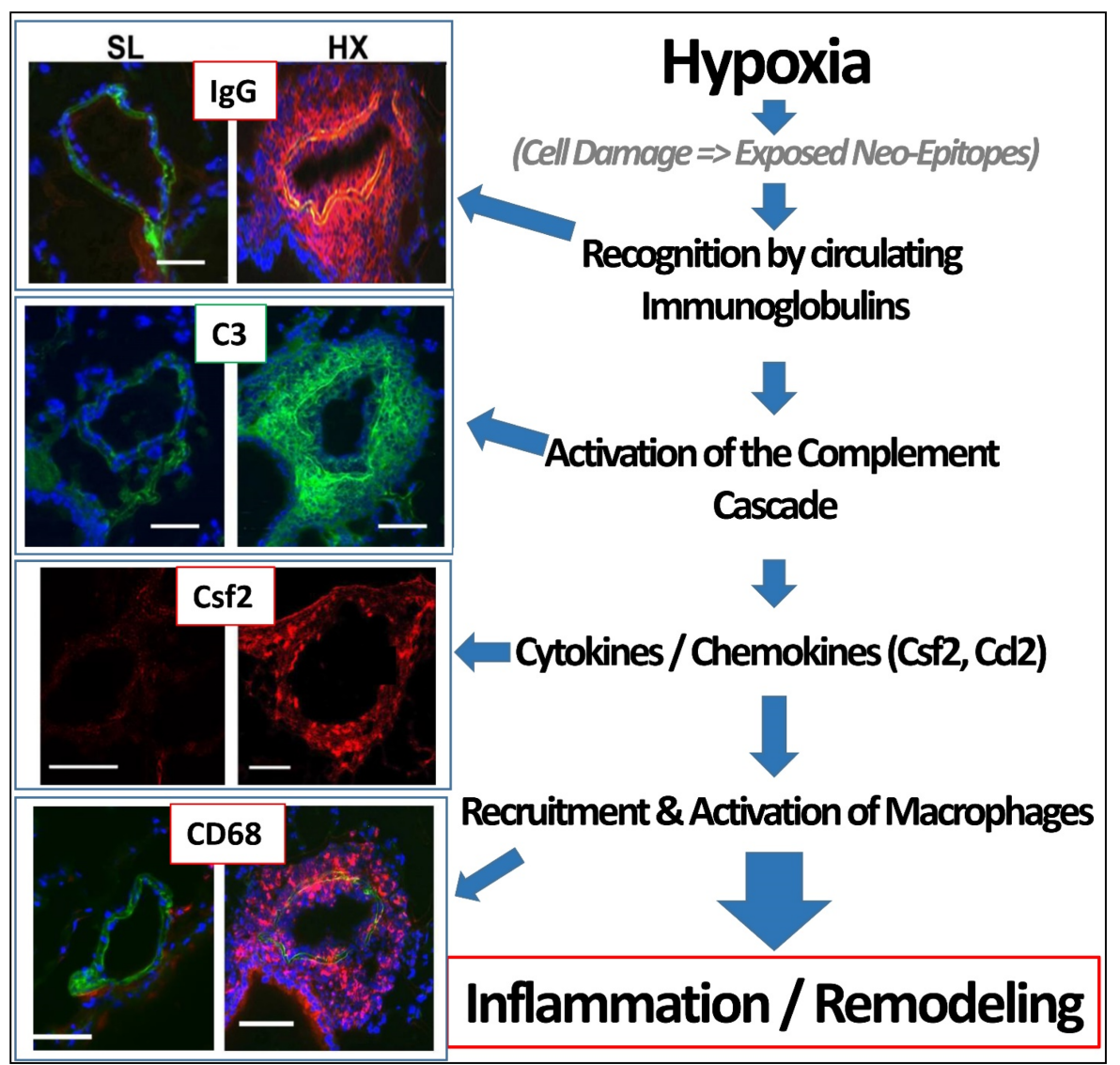

Figure 9. Schematic summary of the presented data, showing immunoglobulin (specifically IgG)-driven activation of the complement cascade, followed by production of pro-inflammatory cytokines/chemokines and recruitment of monocytes/macrophages, resulting in proinflammatory pulmonary vascular remodeling. 
comprising a persistent longitudinal determinant of PAH pathogenesis. Thus, therapeutic strategies utilizing targeted inhibition of local vascular-specific complement activation, and therefore persistent inflammation, may provide a novel approach for the treatment of certain patients with PAH. Because the current approaches for treatment of PAH in already symptomatic patients are limited to "managing" of the disease process, further discovery of novel prognostic targets in the asymptomatic pre-clinical period present an exciting new avenue in the development of more effective prevention and treatment strategies.

\section{REFERENCES}

[1] Humbert M, Guignabert C, Bonnet S, Dorfmuller P, Klinger JR, Nicolls MR, Olschewski AJ, Pullamsetti SS, Schermuly RT, Stenmark KR, Rabinovitch M. Pathology and pathobiology of pulmonary hypertension: state of the art and research perspectives. Eur Respir J. 2019;53. https://www.ncbi.nlm.nih.gov/ pubmed/30545970.

[2] Pullamsetti SS, Perros F, Chelladurai P, Yuan J, Stenmark K. Transcription factors, transcriptional coregulators, and epigenetic modulation in the control of pulmonary vascular cell phenotype: therapeutic implications for pulmonary hypertension (2015 Grover Conference series). Pulm Circ. 2016;6:448-464. https://www.ncbi.nlm.nih.gov/pubmed/28090287.

[3] Erzurum S, Rounds SI, Stevens T, Aldred M, Aliotta J, Archer SL, Asosingh K, Balaban R, Bauer N, Bhattacharya J, Bogaard H, Choudhary G, Dorn 2nd GW, Dweik R, Fagan K, Fallon M, Finkel T, Geraci M, Gladwin MT, Hassoun PM, Humbert M, Kaminski N, Kawut SM, Loscalzo J, McDonald D, McMurtry IF, Newman J, Nicolls M, Rabinovitch M, Shizuru J, Oka M, Polgar P, Rodman D, Schumacker P, Stenmark K, Tuder R, Voelkel N, Sullivan E, Weinshilboum R, Yoder MC, Zhao Y, Gail D, Moore TM. Strategic plan for lung vascular research: an NHLBI-ORDR workshop report. Am J Respir Crit Care Med. 2010;182:1554-1562. https://www.ncbi.nlm.nih.gov/pubmed/20833821.

[4] Stacher E, Graham BB, Hunt JM, Gandjeva A, Groshong SD, McLaughlin VV, Jessup M, Grizzle WE, Aldred MA, Cool CD, Tuder RM. Modern age pathology of pulmonary arterial hypertension. Am J Respir Crit Care Med. 2012;186:261-272. https://www.ncbi.nlm.nih.gov/pubmed/22679007.

[5] Hassoun PM, Mouthon L, Barbera JA, Eddahibi S, Flores SC, Grimminger F, Jones PL, Maitl ML, Michelakis ED, Morrell NW, Newman JH, Rabinovitch M, Schermuly R, Stenmark KR, Voelkel NF, Yuan JX, Humbert M. Inflammation, growth factors, and pulmonary vascular remodeling. I Am Coll Cardiol. 2009;54:S10-19. https://www.ncbi.nlm.nih.gov/pubmed/19555853.

[6] Soon E, Holmes AM, Treacy CM, Doughty NJ, Southgate L, Machado RD, Trembath RC, Jennings S, Barker L, Nicklin P, Walker C, Budd DC, Pepke-Zaba J, Morrell NW. Elevated levels of inflammatory cytokines predict survival in idiopathic and familial pulmonary arterial hypertension. Circulation. 2010;122:920-927. https://www.ncbi.nlm.nih.gov/pubmed/20713898.

[7] Chen GY, Nunez G. Sterile inflammation: sensing and reacting to damage. Nat Rev Immunol. 2010;10:826-837. https://www.ncbi.nlm.nih.gov/pubmed/21088683.

[8] Nicolls MR, Voelkel NF. The roles of immunity in the prevention and evolution of pulmonary arterial hypertension. Am J Respir Crit Care Med. 2017;195:1292-1299. https://www.ncbi.nlm.nih.gov/pubmed/ 27786553.

[9] Buckley CD, Barone F, Nayar S, Benezech C, Caamano J. Stromal cells in chronic inflammation and tertiary lymphoid organ formation. Annu Rev Immunol. 2015;33:715-745. https://www.ncbi.nlm.nih. gov/pubmed/25861980.

[10] Maiellaro K, Taylor WR. The role of the adventitia in vascular inflammation. Cardiovasc Res. 2007;75:640-648. https://www.ncbi.nlm.nih.gov/pubmed/17662969.

[11] Stenmark KR, Yeager ME, El Kasmi KC, Nozik-Grayck E, Gerasimovskaya EV, Li M, Riddle SR, Frid MG. The adventitia: essential regulator of vascular wall structure and function. Annu Rev Physiol. 2013;75:23-47. https://www.ncbi.nlm.nih.gov/pubmed/23216413.

[12] Savai R, Pullamsetti SS, Kolbe J, Bieniek E, Voswinckel R, Fink L, Scheed A, Ritter C, Dahal BK, Vater A, Klussmann S, Ghofrani HA, Weissmann N, Klepetko W, Banat GA, Seeger W, Grimminger F, Schermuly RT. Immune and inflammatory cell involvement in the pathology of idiopathic pulmonary arterial hypertension. Am J Respir Crit Care Med. 2012;186:897-908. https://www.ncbi.nlm.nih.gov/pubmed/ 22955318.

[13] Qian J, Tian W, Jiang X, Tamosiuniene R, Sung YK, Shuffle EM, Tu AB, Valenzuela A, Jiang S, Zamanian RT, Fiorentino DF, Voelkel NF, Peters-Golden M, Stenmark KR, Chung L, Rabinovitch M, Nicolls MR. Leukotriene B4 activates pulmonary artery adventitial fibroblasts in pulmonary hypertension. Hypertension. 2015;66:1227-1239. https://www.ncbi.nlm.nih.gov/pubmed/26558820.

[14] El Kasmi KC, Pugliese SC, Riddle SR, Poth JM, Anderson AL, Frid MG, Li M, Pullamsetti SS, Savai R, Nagel MA, Fini MA, Graham BB, Tuder RM, Friedman JE, Eltzschig HK, Sokol RJ, Stenmark KR. Adventitial fibroblasts induce a distinct proinflammatory/profibrotic macrophage phenotype in pulmonary hypertension. J Immunol. 2014;193:597-609. https://www.ncbi.nlm.nih.gov/pubmed/24928992. 
[15] Bhowmick NA, Neilson EG, Moses HL. Stromal fibroblasts in cancer initiation and progression. Nature. 2004;432:332-337. https://www.ncbi.nlm.nih.gov/pubmed/15549095.

[16] Hu C), Zhang H, Laux A, Pullamsetti SS, Stenmark KR. Mechanisms contributing to persistently activated cell phenotypes in pulmonary hypertension. J Physiol. 2019;597:1103-1119. https://www.ncbi.nlm.nih. gov/pubmed/29920674.

[17] Wang D, Zhang H, Li M, Frid MG, Flockton AR, McKeon BA, Yeager ME, Fini MA, Morrell NW, Pullamsetti SS, Velegala S, Seeger W, McKinsey TA, Sucharov CC, Stenmark KR. MicroRNA-124 controls the proliferative, migratory, and inflammatory phenotype of pulmonary vascular fibroblasts. Circ Res. 2014;114:67-78. https://www.ncbi.nlm.nih.gov/pubmed/24122720.

[18] Zhang H, Wang D, Li M, Plecita-Hlavata L, D’Alessandro A, Tauber J, Riddle S, Kumar S, Flockton A, McKeon BA, Frid MG, Reisz JA, Caruso P, El Kasmi KC, Jezek P, Morrell NW, Hu CJ, Stenmark KR. Metabolic and proliferative state of vascular adventitial fibroblasts in pulmonary hypertension is regulated through a microRNA-124/PTBP1 (Polypyrimidine Tract Binding Protein 1)/pyruvate kinase muscle axis. Circulation. 2017;136:2468-2485. https://www.ncbi.nlm.nih.gov/pubmed/28972001.

[19] Tellides G, Pober JS. Inflammatory and immune responses in the arterial media. Circ Res. 2015;116:312-322. https://www.ncbi.nlm.nih.gov/pubmed/25593276.

[20] Holers VM, Banda NK. Complement in the initiation and evolution of rheumatoid arthritis. Front Immunol. 2018;9:1057. https://www.ncbi.nlm.nih.gov/pubmed/29892280.

[21] Thurman JM, Frazer-Abel A, Holers VM. The evolving landscape for complement therapeutics in rheumatic and autoimmune diseases. Arthritis Rheumatol. 2017;69:2102-2113. https://www.ncbi.nlm. nih.gov/pubmed/28732131.

[22] Ricklin D, Reis ES, Lambris JD. Complement in disease: a defence system turning offensive. Nat Rev Nephrol. 2016;12:383-401. https://www.ncbi.nlm.nih.gov/pubmed/27211870.

[23] Kolev M, Le Friec G, Kemper C. Complement-tapping into new sites and effector systems. Nat Rev Immunol. 2014;14:811-820. https://www.ncbi.nlm.nih.gov/pubmed/25394942.

[24] Hajishengallis G, Reis ES, Mastellos DC, Ricklin D, Lambris JD. Novel mechanisms and functions of complement. Nat Immunol. 2017;18:1288-1298. https://www.ncbi.nlm.nih.gov/pubmed/29144501.

[25] Ricklin D, Lambris JD. Complement in immune and inflammatory disorders: pathophysiological mechanisms. J Immunol. 2013;190:3831-3838. https://www.ncbi.nlm.nih.gov/pubmed/23564577.

[26] Hawksworth OA, Coulthard LG, Woodruff TM. Complement in the fundamental processes of the cell. Mol Immunol. 2017;84:17-25. https://www.ncbi.nlm.nih.gov/pubmed/27894513.

[27] Huber-Lang M, Sarma JV, Zetoune FS, Rittirsch D, Neff TA, McGuire SR, Lambris JD, Warner RL, Flierl MA, Hoesel LM, Gebhard F, Younger JG, Drouin SM, Wetsel RA, Ward PA. Generation of C5a in the absence of C3: a new complement activation pathway. Nat Med. 2006;12:682-687. https://www.ncbi.nlm.nih.gov/ pubmed/16715088.

[28] Medler TR, Murugan D, Horton W, Kumar S, Cotechini T, Forsyth AM, Leyshock P, Leitenberger J), KuleszMartin M, Margolin AA, Werb Z, Coussens LM. Complement C5a fosters squamous carcinogenesis and limits T cell response to chemotherapy. Cancer Cell. 2018;34:561-578 e566. https://www.ncbi.nlm.nih. gov/pubmed/30300579.

[29] Hanahan D, Weinberg RA. Hallmarks of cancer: the next generation. Cell. 2011;144:646-674. https: //www.ncbi.nlm.nih.gov/pubmed/21376230.

[30] Kwak JW, Laskowski J, Li HY, McSharry MV, Sippel TR, Bullock BL, Johnson AM, Poczobutt JM, Neuwelt AJ, Malkoski SP, Weiser-Evans MC, Lambris JD, Clambey ET, Thurman JM, Nemenoff RA. Complement activation via a $\mathrm{C}_{3}$ a receptor pathway alters $\mathrm{CD}_{4}(+) \mathrm{T}$ lymphocytes and mediates lung cancer progression. Cancer Res. 2018;78:143-156. https://www.ncbi.nlm.nih.gov/pubmed/29118090.

[31] Kleczko EK, Kwak JW, Schenk EL, Nemenoff RA. Targeting the complement pathway as a therapeutic strategy in lung cancer. Front Immunol. 2019;10:954. https://www.ncbi.nlm.nih.gov/pubmed/31134065.

[32] Roumenina LT, Daugan MV, Petitprez F, Sautes-Fridman C, Fridman WH. Context-dependent roles of complement in cancer. Nat Rev Cancer. 2019;19:698-715. https://www.ncbi.nlm.nih.gov/pubmed/ 31666715.

[33] Markiewski MM, DeAngelis RA, Benencia F, Ricklin-Lichtsteiner SK, Koutoulaki A, Gerard C, Coukos $\mathrm{G}$, Lambris JD. Modulation of the antitumor immune response by complement. Nat Immunol. 2008;9:1225-1235. https://www.ncbi.nlm.nih.gov/pubmed/18820683.

[34] Bonavita E, Gentile S, Rubino M, Maina V, Papait R, Kunderfranco P, Greco C, Feruglio F, Molgora M, Laface I, Tartari S, Doni A, Pasqualini F, Barbati E, Basso G, Galdiero MR, Nebuloni M, Roncalli M, Colombo P, Laghi L, Lambris JD, Jaillon S, Garlanda C, Mantovani A. PTX 3 is an extrinsic oncosuppressor regulating complement-dependent inflammation in cancer. Cell. 2015;160:700-714. https://www.ncbi. nlm.nih.gov/pubmed/25679762.

[35] Janelle V, Langlois MP, Tarrab E, Lapierre P, Poliquin L, Lamarre A. Transient complement inhibition promotes a tumor-specific immune response through the implication of natural killer cells. Cancer Immunol Res. 2014;2:200-206. https://www.ncbi.nlm.nih.gov/pubmed/24778316.

[36] Nabizadeh JA, Manthey HD, Steyn FJ, Chen W, Widiapradja A, Md Akhir FN, Boyle GM, Taylor SM, Woodruff TM, Rolfe BE. The complement $C_{3}$ a receptor contributes to melanoma tumorigenesis by inhibiting neutrophil and CD4+ T cell responses. J Immunol. 2016;196:4783-4792. https://www.ncbi. nlm.nih.gov/pubmed/27183625.

[37] Wang Y, Sun SN, Liu Q, Yu YY, Guo J, Wang K, Xing BC, Zheng QF, Campa MJ, Patz Jr EF, Li SY, He YW. Autocrine complement inhibits IL 10-dependent T-cell-mediated antitumor immunity to promote tumor progression. Cancer Discov. 2016;6:1022-1035. https://www.ncbi.nlm.nih.gov/pubmed/27297552. 
[38] Guglietta S, Chiavelli A, Zagato E, Krieg C, Gandini S, Ravenda PS, Bazolli B, Lu B, Penna G, Rescigno M. Coagulation induced by $C_{3}$ aR-dependent NETosis drives protumorigenic neutrophils during small intestinal tumorigenesis. Nat Commun. 2016;7:11037. https://www.ncbi.nlm.nih.gov/pubmed/ 26996437.

[39] Frid MG, Brunetti JA, Burke DL, Carpenter TC, Davie NJ, Reeves JT, Roedersheimer MT, van Rooijen N, Stenmark KR. Hypoxia-induced pulmonary vascular remodeling requires recruitment of circulating mesenchymal precursors of a monocyte/macrophage lineage. Am J Pathol. 2006;168:659-669. https://www.ncbi.nlm.nih.gov/pubmed/16436679.

[40] Li M, Riddle SR, Frid MG, El Kasmi KC, McKinsey TA, Sokol RJ, Strassheim D, Meyrick B, Yeager ME, Flockton AR, McKeon BA, Lemon DD, Horn TR, Anwar A, Barajas C, Stenmark KR. Emergence of fibroblasts with a proinflammatory epigenetically altered phenotype in severe hypoxic pulmonary hypertension. J Immunol. 2011;187:2711-2722. https://www.ncbi.nlm.nih.gov/pubmed/21813768.

[41] Nicolls MR, Taraseviciene-Stewart L, Rai PR, Badesch DB, Voelkel NF. Autoimmunity and pulmonary hypertension: a perspective. Eur Respir J. 2005;26:1110-1118. https://www.ncbi.nlm.nih.gov/pubmed/ 16319344.

[42] Park SH, Chen WC, Durmus N, Bleck B, Reibman J, Riemekasten G, Grunig G. The effects of antigenspecific IgG1 antibody for the pulmonary-hypertension-phenotype and B cells for inflammation in mice exposed to antigen and fine particles from air pollution. PLoS One. 2015;10:e0129910. https: //www.ncbi.nlm.nih.gov/pubmed/26079807.

[43] Rabinovitch M, Guignabert C, Humbert M, Nicolls MR. Inflammation and immunity in the pathogenesis of pulmonary arterial hypertension. Circ Res. 2014;115:165-175. https://www.ncbi.nlm.nih.gov/pubmed/ 24951765.

[44] Tieu BC, Lee C, Sun H, Lejeune W, Recinos 3rd A, Ju X, Spratt H, Guo DC, Milewicz D, Tilton RG, Brasier AR. An adventitial IL-6/MCP1 amplification loop accelerates macrophage-mediated vascular inflammation leading to aortic dissection in mice. J Clin Invest. 2009;119:3637-3651. https://www.ncbi. nlm.nih.gov/pubmed/19920349.

[45] Bauer EM, Zheng H, Comhair S, Erzurum S, Billiar TR, Bauer PM. Complement C3 deficiency attenuates chronic hypoxia-induced pulmonary hypertension in mice. PLoS One. 2011;6:e28578. https://www.ncbi. nlm.nih.gov/pubmed/22194859.

[46] Rhodes CJ, Wharton J, Ghataorhe P, Watson G, Girerd B, Howard LS, Gibbs JSR, Condliffe R, Elliot CA, Kiely DG, Simonneau G, Montani D, Sitbon O, Gall H, Schermuly RT, Ghofrani HA, Lawrie A, Humbert M, Wilkins MR. Plasma proteome analysis in patients with pulmonary arterial hypertension: an observational cohort study. Lancet Respir Med. 2017;5:717-726. https://www.ncbi.nlm.nih.gov/ pubmed/28624389.

[47] Zhang J, Zhang Y, Li N, Liu Z, Xiong C, Ni X, Pu Y, Hui R, He J, Pu J. Potential diagnostic biomarkers in serum of idiopathic pulmonary arterial hypertension. Respir Med. 2009;103:1801-1806. https: //www.ncbi.nlm.nih.gov/pubmed/19703762.

[48] Zhang X, Hou HT, Wang J, Liu XC, Yang Q, He GW. Plasma proteomic study in pulmonary arterial hypertension associated with congenital heart diseases. Sci Rep. 2016;6:36541. https://www.ncbi.nlm. nih.gov/pubmed/27886187.

[49] Hill RC, Calle EA, Dzieciatkowska M, Niklason LE, Hansen KC. Quantification of extracellular matrix proteins from a rat lung scaffold to provide a molecular readout for tissue engineering. Molecular \& Cellular Proteomics: MCP. 2015;14:961-973. http://www.ncbi.nlm.nih.gov/pubmed/25660013.

[50] Calle EA, Hill RC, Leiby KL, Le AV, Gard AL, Madri JA, Hansen KC, Niklason LE. Targeted proteomics effectively quantifies differences between native lung and detergent-decellularized lung extracellular matrices. Acta Biomater. 2016;46:91-100. https://www.ncbi.nlm.nih.gov/pubmed/27693690.

[51] Gaetani R, Aouad S, Demaddalena LL, Straessle H, Dzieciatkowska M, Wortham M, Bender HR, NguyenNgoc K-V, Schmid-Schoenbein GW, George SC, Hughes CCW, Sander M, Hansen KC, Christman KL. Evaluation of different decellularization protocols on the generation of pancreas-derived hydrogels. Tissue Engineering Part C, Methods. 2018. http://www.ncbi.nlm.nih.gov/pubmed/30398401.

[52] Merna N, Fung KM, Wang JJ, King CR, Hansen KC, Christman KL, George SC. Differential $\beta 3$ integrin expression regulates the response of human lung and cardiac fibroblasts to extracellular matrix and its components. Tissue Engineering Part A. 2015;21:2195-2205. http://www.ncbi.nlm.nih.gov/pubmed/ 25926101.

[53] Hansen KC, Kiemele L, Maller O, O’Brien J, Shankar A, Fornetti J, Schedin P. An in-solution ultrasonication-assisted digestion method for improved extracellular matrix proteome coverage. Molecular \& Cellular Proteomics: MCP. 2009;8:1648-1657. http://www.ncbi.nlm.nih.gov/pubmed/ 19351662.

[54] Hattar R, Maller O, McDaniel S, Hansen KC, Hedman KJ, Lyons TR, Lucia S, Wilson RS, Schedin P. Tamoxifen induces pleiotrophic changes in mammary stroma resulting in extracellular matrix that suppresses transformed phenotypes. Breast Cancer Research: BCR. 2009;11:R5. http://www.ncbi.nlm. nih.gov/pubmed/19173736.

[55] Laklai H, Miroshnikova YA, Pickup MW, Collisson EA, Kim GE, Barrett AS, Hill RC, Lakins JN, Schlaepfer DD, Mouw JK, LeBleu VS, Roy N, Novitskiy SV, Johansen JS, Poli V, Kalluri R, lacobuzio-Donahue CA, Wood LD, Hebrok M, Hansen K, Moses HL, Weaver VM. Genotype tunes pancreatic ductal adenocarcinoma tissue tension to induce matricellular fibrosis and tumor progression. Nature Medicine. 2016;22:497-505. http://www.ncbi.nlm.nih.gov/pubmed/27089513. 
[56] O’Brien J, Hansen K, Barkan D, Green J, Schedin P, O’Brien J, Hansen K, Barkan D, Green J, Schedin P. Non-steroidal anti-inflammatory drugs target the pro-tumorigenic extracellular matrix of the postpartum mammary gland. Int J Dev Biol. 2011;55:745-755. https://www.ncbi.nlm.nih.gov/pubmed/22161831.

[57] Tomko LA, Hill RC, Barrett A, Szulczewski JM, Conklin MW, Eliceiri KW, Keely PJ, Hansen KC, Ponik SM. Targeted matrisome analysis identifies thrombospondin-2 and tenascin- $C$ in aligned collagen stroma from invasive breast carcinoma. Scientific Reports. 2018;8:12941. http://www.ncbi.nlm.nih.gov/ pubmed/30154546.

[58] Barrett AS, Wither MJ, Hill RC, Dzieciatkowska M, D’Alessandro A, Reisz JA, Hansen KC. Hydroxylamine chemical digestion for insoluble extracellular matrix characterization. Journal of Proteome Research. 2017;16:4177-4184. http://www.ncbi.nlm.nih.gov/pubmed/28971683.

[59] Goddard ET, Hill RC, Barrett A, Betts C, Guo Q, Maller O, Borges VF, Hansen KC, Schedin P. Quantitative extracellular matrix proteomics to study mammary and liver tissue microenvironments. Int J Biochem Cell Biol. 2016;81:223-232. https://www.ncbi.nlm.nih.gov/pubmed/27771439.

[6o] Goddard ET, Hill RC, Nemkov T, D’Alessandro A, Hansen KC, Maller O, Mongoue-Tchokote S, Mori M, Partridge AH, Borges VF, Schedin P. The rodent liver undergoes weaning-induced involution and supports breast cancer metastasis. Cancer Discov. 2017;7:177-187. https://www.ncbi.nlm.nih.gov/ pubmed/27974414.

[61] O’Brien JH, Vanderlinden LA, Schedin PJ, Hansen KC. Rat mammary extracellular matrix composition and response to ibuprofen treatment during postpartum involution by differential GeLC-MS/MS analysis. J Proteome Res. 2012;11:4894-4905. https://www.ncbi.nlm.nih.gov/pubmed/22897585.

[62] Beynon RJ, Doherty MK, Pratt JM, Gaskell SJ. Multiplexed absolute quantification in proteomics using artificial QCAT proteins of concatenated signature peptides. Nature Methods. 2005;2:587-589. http: //www.nature.com/nmeth/journal/v2/n8/full/nmeth774.html.

[63] Rivers J, Simpson DM, Robertson DHL, Gaskell SJ, Beynon RJ. Absolute multiplexed quantitative analysis of protein expression during muscle development using QconCAT. Molecular \& Cellular Proteomics. 2007;6:1416-1427. http://www.mcponline.org/content/6/8/1416, http://www.ncbi.nlm.nih.gov/ pubmed/17510050.

[64] Stenmark KR, Fasules J, Hyde DM, Voelkel NF, Henson J, Tucker A, Wilson H, Reeves JT. Severe pulmonary hypertension and arterial adventitial changes in newborn calves at $4300 \mathrm{~m}$. J Appl Physiol (1985). 1987;62:821-830. https://www.ncbi.nlm.nih.gov/pubmed/3558241.

[65] Thurman JM, Kulik L, Orth H, Wong M, Renner B, Sargsyan SA, Mitchell LM, Hourcade DE, Hannan JP, Kovacs JM, Coughlin B, Woodell AS, Pickering MC, Rohrer B, Holers VM. Detection of complement activation using monoclonal antibodies against C3d. J Clin Invest. 2013;123:2218-2230. https://www. ncbi.nlm.nih.gov/pubmed/23619360.

[66] Frid MG, McKeon BA, Thurman JM, Maron BA, Li M, Zhang H, Kumar S, Sullivan T, Laskowsky J, Fini MA, Hu S, Tuder RM, Gandjeva A, Wilkins MR, Rhodes CJ, Ghataorhe P, Leopold JA, Wang RS, Holers VM, Stenmark KR. Immunoglobulin-driven complement activation regulates proinflammatory remodeling in pulmonary hypertension. Am J Respir Crit Care Med. 2020;201:224-239. https://www.ncbi.nlm.nih. gov/pubmed/31545648.

[67] Thurman JM. Triggers of inflammation after renal ischemia/reperfusion. Clin Immunol. 2007;123:7-13. https://www.ncbi.nlm.nih.gov/pubmed/17064966.

[68] Sawada H, Saito T, Nickel NP, Alastalo TP, Glotzbach JP, Chan R, Haghighat L, Fuchs G, Januszyk M, Cao A, Lai YJ, Perez Vde J, Kim YM, Wang L, Chen PI, Spiekerkoetter E, Mitani Y, Gurtner GC, Sarnow P, Rabinovitch M. Reduced BMPR2 expression induces GM-CSF translation and macrophage recruitment in humans and mice to exacerbate pulmonary hypertension. J Exp Med. 2014;211:263-280. https: //www.ncbi.nlm.nih.gov/pubmed/24446489.

[69] Becher B, Tugues S, Greter M. GM-CSF: from growth factor to central mediator of tissue inflammation. Immunity. 2016;45:963-973. https://www.ncbi.nlm.nih.gov/pubmed/27851925.

[70] Croxford AL, Lanzinger M, Hartmann FJ, Schreiner B, Mair F, Pelczar P, Clausen BE, Jung S, Greter M, Becher B. The cytokine GM-CSF Drives the inflammatory signature of CCR2+ monocytes and licenses autoimmunity. Immunity. 2015;43:502-514. https://www.ncbi.nlm.nih.gov/pubmed/26341401.

[71] Florentin J, Coppin E, Vasamsetti SB, Zhao J, Tai YY, Tang Y, Zhang Y, Watson A, Sembrat J, Rojas M, Vargas SO, Chan SY, Dutta P. Inflammatory macrophage expansion in pulmonary hypertension depends upon mobilization of blood-borne monocytes. J Immunol. 2018;200:3612-3625. https://www.ncbi.nlm. nih.gov/pubmed/29632145.

[72] Kitamura D, Roes J, Kuhn R, Rajewsky K. A B cell-deficient mouse by targeted disruption of the membrane exon of the immunoglobulin mu chain gene. Nature. 1991;350:423-426. https://www.ncbi. nlm.nih.gov/pubmed/1901381.

[73] Klein-Schneegans AS, Kuntz L, Fonteneau P, Loor F. Serum concentrations of IgM, IgG1, IgG2b, IgG3 and IgA in $\mathrm{C}_{57} \mathrm{BL} / 6$ mice and their congenics at the Ipr (lymphoproliferation) locus. J Autoimmun. 1989;2:869-875. https://www.ncbi.nlm.nih.gov/pubmed/2619870.

[74] Jolles S, Orange JS, Gardulf A, Stein MR, Shapiro R, Borte M, Berger M. Current treatment options with immunoglobulin $\mathrm{G}$ for the individualization of care in patients with primary immunodeficiency disease. Clin Exp Immunol. 2015;179:146-160. https://www.ncbi.nlm.nih.gov/pubmed/25384609.

[75] Colvin KL, Cripe PJ, Ivy DD, Stenmark KR, Yeager ME. Bronchus-associated lymphoid tissue in pulmonary hypertension produces pathologic autoantibodies. Am J Respir Crit Care Med. 2013;188:1126-1136. https://www.ncbi.nlm.nih.gov/pubmed/24093638. 
Page 18 of 18

Fid et al. GCSP 2020:1

[76] Karsten CM, Kohl J. The immunoglobulin, lG FC receptor and complement triangle in autoimmune diseases. Immunobiology. 2012;217:1067-1079. https://www.ncbi.nlm.nih.gov/pubmed/22964232.

[77] Chou HF, Man H, Bertram P, Mu Y, Springer LE, Thompson RW, Curci JA, Hourcade DE, Sham CT. Fibrinogen-specific antibody induces abdominal aortic aneurysm in mice through complement lection pathway activation. Proc Natl Acad Sci U S A. 2013;110:E4335-4344. https://www.ncbi.nlm.nih.gov/ pubmed/24167262.

[78] Holodick NE, Rodriguez-Zhurbenko N, Hernandez AM. Defining natural antibodies. Front Immunol. 2017;8:872. https://www.ncbi.nlm.nih.gov/pubmed/28798747.

[79] Hemnes AR, Beck GJ, Newman JH, Abidov A, Aldred MA, Barnard J, Berman Rosenzweig E, Borlaug BA, Chung WK, Comhair SAA, Erzurum SC, Frantz RP, Gray MP, Grunig G, Hassoun PM, Hill NS, Horn EM, Mu B, Lempel JK, Aaron BA, Mathai SC, Oman MA, Richard FP, Systrom DM, Tang WHW, Taxman AB, Ciao L, Yuan JX, Leopold JA, Group PS. PVDOMICS: a multi-center study to improve understanding of pulmonary vascular disease through phenomics. Circ Res. 2017;121:1136-1139. https://www.ncbi.nlm. nih.gov/pubmed/29074534.

[80] Sweet AJ, Hedlin HK, Balasubramanian V, Hi A, Blum LK, Robinson WH, Haddad F, Hickey PM, Condliffe R, Lawrie A, Nicolls MR, Rabinovitch M, Khatri P, Zamanian RT. Discovery of distinct immune phenotypes using machine learning in pulmonary arterial hypertension. Cir Res. 2019;124:904-919. https://www.ncbi.nlm.nih.gov/pubmed/30661465. 